\title{
NOTEZ BIEN
}

le 28 et le 29 ma 1986

Le congrès national de

L'ASSOCIATION CANADIENNE DES PROFESSEURS DE RÉDACTION TECHNIQUE ET SCIENTIFIQUE

dans le cadre

du

CONGRẼS DES SOCIËTIÉS SAVANTES

UNIVERSITY OF MANITOBA

WINNIPEG, MANITOBA

\section{REMEMBER}

May 28 and 291986

THE CANADIAN ASSOCIATION OF TEACHERS OF TECHNICAL WRITING

meets for its national conference during the

LEARNED SOCIETIES CONFERENCE

UNIVERSITY OF MANITOBA

WINNIPEG, MANITOBA 
